\title{
Index to Volume 9
}

\author{
Citation refers to Issue Number and Page Number
}

Number Page

Acadian deformation in Maine-New Brunswick, the age of the: DONOHOE

Age, the, of the Acadian deformation in Maine-New Brunswick: DONOHOE

AKPATI, B.N., Observations on the effects of islets and shoals on salinity distribution in an estuarine regime

Analysis, environmental, of continental margins, mesa: interdisciplinary approach to: SWIFT

Analysis, facies, of the Pennsylvania Pictou Group in New Brunswick, Stratigraphy, sediment dispersal and: VAN DE POLL

Approach, interdisciplinary, to environmental analysis of continental margins, mesa: SWIFT

Baffin Bay, a late Quaternary stratigraphic marker in the central basin of: PIPER

Basin, central, of Baffin Bay, a late quaternary stratigraphic marker in the: PIPER

Battery Point Formation, Gaspé Est, Quebec, Devonian braided stream deposits in the: CANT

Bay, Baffin, a late Quaternary stratigraphic marker in the central basin of: PIPER

Bay, Cobequid, Bay of Fundy, preliminary investigations of an intertidal sand body: DALRYMPLE

Fay of Fundy, preliminary investigations of an intertidal sand body, Cobequid Bay: DALRYMPLE,

Body, sand, intertidal Cobequid Bay, Bay of Fundy, preliminary investigations of an: DALRYMPLE

Briaded stream deposits, Devonian, in the Battery Point Formation, Gaspe Est, Quebec: CANT

Brief summary of the Late Precambrian rocks in the Caledonian Highlands of southern New Brunswick, a: RUITENBERG

Caledonian Highlands of southeastern New Brunswick, a brief summary of the Late Paleozoic in the: RUITENBERG

3

CANT, D.J., Devonian braided stream deposits in the Battery Point Formation, Gaspé Est, Quebec

Cape Breton Island, Precambrian rocks of: WIEBE

Cape Breton Island, southeast, Nova Scotia, Pre-Carboniferous structural history of: HELMSTAEDT

Central basin of Baffin Bay, a late Quaternary stratigraphic marker in the: PIPER

quid Bay, Bay of Fundy, preliminary investigation of an intertidal sand body: DALRYMPIE

78
COK, A., see SWIFT

Continental margins, mesa: interdisciplinary approach to environmental analysis of: SWIFT

Number Page

Numer

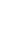

37

DALRYMPLE, R.W., preliminary investigations of an intertidal sand body, Cobequid Bay, Bay of Fundy

DALRYMPLE, R.W., sediment texture and transport studies in an intertidal environment: A progress report

Deformation, Acadian, of the, in MaineNew Brunswick, the age: DONOHOE

Deposits, stream, braided, Devonian in the Battery Point Formation, Gaspê Est, Quebec: CANT

2

2

Devonian braided stream deposits in the Battery Point Formation, Gaspé Est, Quebec: CANT

Dispersal, sediment, and facies analysis of the Pennsylvania Pictou Group in New Brunswick, stratigraphy: VAN DE POLE

Distribution, salinity, in an estuarine regime, observations on the effects of islets and shoals on: AKPATI

(1)

DONOHOE, H.V., Jr., and PAJARIE, G., The age of the Acadian deformation in Maine-New Brunswick 3

DRAKE, D., see SWIFT . 2

78

Effects of islets and shoals on salinity distribution in an estuarine regime, observations on the: AKPATI

Environmental analysis of continental margins, mesa: interdisciplinary approach to: SWIFT

Environmental intertidal: A progress report, sediment texture and transport studies in an: DALRYMPLE 2 Environments, sedimentary: A study for students, a re-examination of the silt/clay ratios as indicators of: PELLETIER

Estuarine regime, observations on the effects of islets and shoals on salinity distribution in an: AKPATI 2

Facies analysis of the Pennsylvania Pictou Group in New Brunswick, stratigraphy, sediment dispersal and: VAN DE POLL 3

Formation, Battery Point, Gaspé Est, Quebec, Devonian braided stream deposits in the: CANT

FREELAND, G., see SWIFT

Fundy, Bay of, preliminary investigations of an intertidal sand body, Cobequid Bay: DALRYMPLE

Gaspé Est, Quebec, Devonian braided stream deposits in the Battery Point Formation: CANT 
Brunswick, stratigraphy, sediment dispersal and facies analysis of the: VAN DE POIL

\section{3}

2

HATCHER, P., see SWIFT, D.

HELMSTAEDT, H., and TELLA, S., Pre-

Carboniferous structural history of southeast Cape Breton Island, Nova Scotia

3

Highlands, Caledonian, of southeastern New Brunswick, a brief summary of the Late Paleozoic rocks in the: RUITENBERG

History, structural, Pre-Carboniferous, of southeast Cape Breton Island, Nova Scotia: HELMSTAEDT

Indicators of sedimentary environments: A study for students, a re-examination of the use of the silt/clay ratios: PELIETIER

Interdisciplinary approach to environmental analysis of continental margins, mesa: SWIFT

rtidal environment: A progress report, sediment texture and transport studies in an: DALRYMPLE

Intertidal sand body, Cobequid Bay, Bay of Fundy, preliminary investigations of an: DALRYMPLE

Investigations, preliminary, of an intertidal sand body, Cobequid Bay, Bay of Fundy: DALRYMPLE

Island, Cape Breton, Precambrian rocks of: WIEBE

Island, Cape Breton, southeast, Nova Scotia, Pre-Carboniferous structural history of: HELMSTAEDT

Islets and shoals on salinity distribution in an estuarine regime, observations on the effects of: AKPATI

KELLER, G., see SWIFT

Late Paleozoic rocks in the Caledonian Highlands of southeastern New Brunswick, a brief summary of the: RUITENBERG

Late, a, Quaternary stratigraphic marker in the central basin of Baffin Bay: PIPER

LAVELLE, W., see SWIFT

MCCUTCHEON, S.R. SEe RUITENBERG

MCKINNEY, T., see SWIFT

Maine-New Brunswick, the age of the Acadian deformation in: DONOHOE

Margins, continental, mesa: interdisciplinary approach to environmental analysis of: SWIFT a, in the central basin of Baffin Bay: PIPER

Mesa: interdisciplinary approach to environmental analysis of continental margins: SWIFT

NELSEN, T., see SWIFT

New Brunswick, southeastern, a brief summary of the Late Paleozoic rocks in the Caledonian Highlands of: RUITENBERG

3

New Brunswick, stratigraphy, sediment dispersal and facies analysis of the Pennsylvania Pictou Group in:

VAN DE POLL

Nova Scotia, Pre-Carboniferous structural history of southeast Cape Breton Island: HELMSTAEDT

Observations on the effects of islets and shoals on salinity distribution in an estuarine regime: AKPATI

PAJARIE, G., see DONOHOE

Paleozoic rocks in the Caledonian Highlands of southeastern New Brunswick, a brief summary of the Late: RUITENBERG

PELLETIER, B.R., A re-examination of the use of the silt/clay ratios as indicators of sedimentary environments: A study for students

Pennsylvania Pictou Group in New Brunswick, stratigraphy, sediment dispersal and facies analysis of the: VAN DE POLL

Pictou Group, Pennsylvania, in New Brunswick, stratigraphy, sediment dispersal and facies analysis of the: VAN DE POLL

PIPER, D.J.W., A late Quaternary stratigraphic marker in the central basin of Baffin Bay

Pre-Carboniferous structural history of southeast Cape Breton Island, Nova Scotia: HELMSTAEDT

Precambrian rocks of Cape Breton Island: WIEBE

Preliminary investigations of the intertidal sand body, Cobequid Bay, Bay of Fundy: DALRYMPLE

Quaternary, late, a, stratigraphic marker in the central basin of Baffin Bay : PIPER

Quebec, Devonian braided stream deposits in the Battery Point Formation, Gaspé Est: CANT

Ratios, silt/clay, as indicators of sedimentary environments: A study for students, a re-examination of the use of the: PELLETIER

Re-examination of the use of the silt/ clay ratios as indicators of sedimentary environments: A study for students, a: PELLETIER

Regime, estuarine, observations on the effects of islets and shoals on salinity distribution in an: AKPATI 2

Rocks, Paleozoic, Late, in the Caldeonian Highlands of southeastern New Brunswick, a brief summary of the: RUITENBERG

Rocks, Precambrian, of Cape Breton Island: WIEBE 
RUITENBERG, A.A., GILES, P.S., VENUGOPAL, D.V., and MCCUTCHEON, S.R., A brief summary of the Late Precambrian rocks in the Caledonian Highlands of southern New Brunswick

Salinity distribution in an estuarine regime, observations on the effects of islets and shoals on: AKPATI

Sand body, intertidal, Cobequid Bay, Bay of Fundy, preliminary investigations of an: DALRYMPLE

Sedimentary environments: A study for students, a re-examination of the use of the silt/clay ratios as indicators of: PELLETIER

Sediment dispersal and facies analysis of the Pennsylvania Pictou Group in New Brunswick, stratigraphy: VAN DE POLI

sediment texture and transport studies in an intertidal environment: A progress report: DALRYMPLE

s on salinity distribution in an estuarine regime, observations on the effects of islets and: AKPATI

Silt/clay ratios as indicators of sedimentary environments: A study for students, a re-examination of the use of the: PELLETIER

Southeast Cape Breton Island, Nova Scotia, Pre-Carboniferous structural history of: HELMSTAEDT

Southeastern New Brunswick, a brief summary of the Late Paleozoic rocks in the Caledonian Highlands of: RUI'TENBERG

Stratigraphic, Quaternary; late, a marker in the central basin of Baffin Bay: PIPER

Stratigraphy, sediment dispersal and facies analysis of the Pennsylvania Pictou Group in New Brunswick: VAN DE POLL 3

Stream deposits, braided, Devonian, in the Battery Point Formation, Gaspe Est, Quebec: CANT

Structural history, Pre-Carboniferous, of southeast Cape Breton Island, Nova Scotia: HELMSTAEDT

STUBBLEFIELD, W., see SWIFT

$3 \quad 88$

Students, a re-examination of the use of the silt/clay ratios as indicators of sedimentary environments: A study for: PEILETIER

Study, a, for students, a re-examination of the use of the silt/clay ratios as indicators of sedimentary environments: PELLETIER

Studies, transport, in an intertidal environment: A progress report, sediment texture and: DALRYMPLE $y$, a brief, of the Late Paleozoic rocks in the Caledonian Highlands of southeastern New Brunswick: RUITENBERG ciplinary approach to environmental analysis of continental margins

TELLA, S., see HELMSTAEDT, $\mathrm{H}$.

Texture, sediment, and transport studies in an intertidal environment: A progress report: DALRYMPLE 2

Transport studies in an intertidal environment: A progress report, sediment texture and: DALRYMPLE

Use of the silt/clay ratios as indicators of sedimentary environments: A study for students, a re-examination of the: PELLETIER

VAN DE POLL, H.W., Stratigraphy, sediment dispersal and facies analysis of the Pennsylvania Pictou Group in New Brunswick VENUGOPAL, D.V, , see RUITENBERG

WIEBE, R.A., Precambrian rocks of Cape Breton Island

SWIFT, D., FREELAND, G., DRAKE, D., HATCHER, P., KELLER, G., LAVELLE, W., NELSEN, T., STUBBLEFIELD, W., COK, A., and MCKINNEY, T., Mesa: interdis- 